\title{
Kajian Atmosfir Terkendali untuk Memperlambat Penurunan Mutu Buah Mangga Arumanis selama Penyimpanan
}

\section{Study on controlled atmosphere to decelerate the deterioration of arumanis mango during storage}

\author{
I Made Supartha Utama ${ }^{1 *}$, Yohanes Setiyo ${ }^{1}$, Ida Ayu Rina Pratiwi Puja ${ }^{1}$ dan Nyoman Semadi Antara ${ }^{2}$ \\ Diterima 17 Oktober 2010/Disetujui 18 Maret 2011
}

\begin{abstract}
Arumanis Mango (Mangifera indica L. cv Arumanis) which is one of Indonesia's tropical fruits having a high potency to be developed as an export commodity. Limited volumes of the fruit have been exported using air cargo and attempts in using sea freights with reefer containers for long distance market had not given convincing result. Therefore, efforts in optimizing the use of a reefer container are essential. Investigations, were performed in order to decelerate the deterioration fruits which involved different combined concentrations of $\mathrm{O}_{2}$ and $\mathrm{CO}_{2}$ gases during storage of Arumanis mango at cold $\left(12 \pm 1.5^{\circ} \mathrm{C}\right)$ and room $\left(28+2^{\circ} \mathrm{C}\right)$ temperatures. Four different combined gases of $\mathrm{O}_{2}$ and $\mathrm{CO}_{2}$, namely $5 \% \mathrm{O}_{2}$ and $5 \% \mathrm{CO}_{2} ; 5 \% \mathrm{O}_{2}$ and $10 \% \mathrm{CO}_{2} ; 10 \% \mathrm{O}_{2}$ and $5 \% \mathrm{CO}_{2}$; and $10 \% \mathrm{O}_{2}$ and $10 \% \mathrm{CO}_{2}$ were surged surrounding the fruits stored at the cold and room temperatures. Fruits without treatments with the combined gases were prepared as kontrols. The investigation indicated that the cold temperature of storage was still the best way to slowing down the deterioration of the fruit. There were no significant different effects on the rate of deterioration among the fruits treated with the different combined concentrations of $\mathrm{O}_{2}$ and $\mathrm{CO}_{2}$. The controlled atmospheres, however, were better for storing the fruits compared to those stored without controlled atmosphere.
\end{abstract}

Key words: controlled atmosphere, Arumanis, mango

\section{PENDAHULUAN}

Indonesia merupakan salah satu produsen Mangga (Mangifera indica L.) dengan keragaman varietas tinggi. Namun, Indonesia masih memberikan kontribusi produksi relatif kecil yaitu sekitar 5\% dari produksi mangga dunia. Negara produsen terbesar adalah India (51\%). Di Asia, negara penghasil mangga yang cukup berarti selain Indonesia ialah Cina (9\%), Thailand (6\%), Pakistan (4\%) dan Philipina (2\%). Dari segi ekspor, walau Indonesia menunjukkan peningkatan berarti dari tahun ke tahun, tetapi dibandingkan dengan produksinya sendiri maka ekspor tersebut masih sangat rendah, yaitu (0.07\%) (BPS, 2007). Peningkatan ekspor terjadi karena perkembangan pasar-pasar baru di Timur Tengah seperti Uni Emirat Arab, Saudi Arabia, Kuwait, Qatar dan Bahrain.

Ada dua kultivar mangga di Indonesia yang mempunyai potensi untuk lebih dikembangkan sebagai komoditas ekspor yaitu varietas Arumanis dan Gedong Gincu. Mangga Arumanis tersebar hampir di seluruh propinsi. Mangga Arumanis mempunyai keunggulan karena citarasanya yang khas dengan tekstur lembut, creamy dengan sedikit serat. Peluang untuk ekspor jenis mangga ini sangat tinggi karena jenis yang sama tidak dihasilkan oleh negara penghasil dan pengekspor mangga dunia yaitu India, Meksiko dan negara Amerika Latin lainnya.

Permasalahan penting untuk pengembangan pasar ekspor, khususnya untuk pasar international yang jaraknya relatif jauh seperti Negara Timur Tengah, Eropa dan Amerika Serikat, ialah biaya yang tinggi karena pengirimannya menggunakan pesawat udara. Uji coba dengan menggunakan container berpendingin (reefer container) dengan pengiriman melalui laut ke Timur Tengah yang membutuhkan waktu tempuh 16-21 hari, belum memberikan hasil maksimal. Hal ini disebabkan, di samping adanya kerusakan dingin akibat kurang seragamnya kematangan, juga karena buah mangga telah mengalami pemasakan setelah sampai di negara tujuan. Walaupun dapat dipasarkan, tetapi waktu pemasaran di Negara tujuan relatif singkat. Uji coba pengiriman lewat laut telah pula dilakukan oleh Pemerintah Australia Utara untuk mangga Kengsington Pride ke Guangzhou di tahun 2001 (Thom et al., 2002) dengan permasalahan utama yang dihadapi ialah melembeknya buah (fruit softening), karena proses pemasakan.

Dengan perkembangan teknologi sekarang ini dan permasalahan ekspor tersebut, perusahaanperusahaan pelayaran telah mengembangkan container berpendingin dengan konsentrasi gas oksigen $\left(\mathrm{O}_{2}\right)$ dan karbondioksida $\left(\mathrm{CO}_{2}\right)$ dapat

\footnotetext{
${ }^{1}$ Jurusan Teknik Pertanian, Fakultas Pertanian, Universitas Udayana, Kampus Bukit Jimbaran, Badung, Bali,

Phone/fax: +62 361 701801, Email : suparthautama@ymail.com

(*Penulis untuk korespondensi)

Jurusan Teknologi Industri Pertanian, Fakultas Pertanian, Universitas Udayana, Kampus Bukit Jimbaran, Badung,

Bali, Phone/fax: +62 361701801
} 
dikendalikan di dalam atmosfir container atau disebut Controlled Atmosphere-Reefer Container $(C A R C)$. Hal ini bertujuan untuk mengatasi permasalahan tersebut terutama untuk pemasaran buah mangga dengan jarak relatif jauh. Agar dapat menggunakan CARC sangat diperlukan penelitian untuk mendapatkan kondisi optimum kombinasi kedua gas tersebut untuk spesifik varietas mangga, seperti halnya mangga Arumanis.

Teknik atmosfir terkendali sekitar produk bertujuan untuk mengendalikan metabolisme produk segar sehingga masa simpan dapat diperpanjang. Konsentrasi gas $\mathrm{O}_{2}$ dan/atau $\mathrm{CO}_{2}$ di sekitar produk segar dijaga pada suatu konsentrasi yang diinginkan. Dengan adanya pengendalian kedua gas tersebut akan terjadi hambatan laju respirasi sehingga laju respirasi relatif rendah pada batas tidak menimbulkan kondisi respirasi anaerobic pada produk segar tersebut.

Memperhatikan manfaat dari teknologi atmosfir terkendali tersebut, maka eksplorasi pemanfaatannya untuk buah-buah tropis potensial sangat penting dilakukan. Salah satu produk buah tropis yang mempunyai pasar potensial baik di dalam maupun luar negeri ialah buah mangga Arumanis. Artikel ini merupakan laporan hasil kajian teknologi atmosfir terkendali tersebut terhadap buah mangga Arumanis.

\section{BAHAN DAN METODE}

Bahan utama penelitian ini ialah buah mangga Arumanis yang telah matang $75 \%$. Buah dikoleksi dari satu kebun petani di Desa Depeha, Kecamatan Kubutambahan, Kabupaten Buleleng, Provinsi Bali. Buah diseleksi dan buah cacat dibuang seperti buah lecet, memar, busuk, buah telah masak, adanya tanda pembusukan pada bagian pangkal buah, dan sebagainya untuk mengendalikan homogenitas bahan.

Penelitian ini menggunakan empat ragam kombinasi gas terkendali yaitu $5 \% \mathrm{O}_{2}$ dan $5 \% \mathrm{CO}_{2}$; $5 \% \mathrm{O}_{2}$ dan $10 \% \mathrm{CO}_{2} ; 10 \% \mathrm{O}_{2}$ dan $5 \% \mathrm{CO}_{2} ; 10 \% \mathrm{O}_{2}$ dan $10 \% \mathrm{CO}_{2}$, serta kontrol disediakan untuk melihat efektifitas perlakuan tersebut. Empat kombinasi komposisi gas yang khusus dibeli dengan tabung berbeda dialirkan secara terkendali (controlled flow through system) dengan menggunakan double stage regulator pada masing-masing tabung ke dalam gas tight plastic chambers di dalam cold storage yang di dalamnya ditempatkan buah mangga Arumanis. Chamber yang sama ditempatkan pula pada suhu kamar untuk mengetahui efectivitas controlled atmosphere ini tanpa kombinasi dengan pendingin.
Untuk memastikan bahwa konsentrasi kedua gas $\mathrm{O}_{2}$ dan $\mathrm{CO}_{2}$ di dalam chambers sesuai dengan kombinasi gas perlakuan maka setiap hari konsentrasinya diperiksa menggunakan pengukur gas $\mathrm{O}_{2}$ (Cosmotector tipe XP-318) dan $\mathrm{CO}_{2}$ (Cosmotector tipe XP-314). Bila terjadi sedikit penyimpangan maka aliran gas segera diatur melalui regulator pada masing-masing tabung. Instalasi controlled atmosphere tersebut dapat dilihat pada Gambar 1.

Percobaan dilakukan dengan rancangan acak lengkap dengan dua faktor yaitu perlakuan komposisi gas dan suhu penyimpanan yang mana suhu penyimpanan ini sama dengan suhu pada penelitian pertama. Percobaan diulang tiga kali dengan unit percobaan masing-masing 20 buah mangga Arumanis. Penyimpanan dilakukan sampai 50 hari dan pengamatan terhadap parameter penelitian dilakukan setiap periode 5 hari penyimpanan.

Peubah pengamatan yaitu: (1) Kekerasan Buah, kekerasan buah diukur dengan menggunakan texture analyser (TA.XTplus, England). Alat texture analyser dihubungkan dengan perangkat komputer yang dilengkapi dengan software "Texture Exponent 32". Probe yang digunakan pada alat ini adalah probe bentuk silinder panjang dengan diameter 0.5 $\mathrm{cm}$. Nilai kekerasan secara langsung diperlihatkan pada komputer dengan satuan kg yang merupal tenaga dibutuhkan oleh probe untuk menekan dan memecah jaringan dermal daging buah. (2) Padatan Terlarut Total (PTT), pengukuran total padatan terlarut dilakukan dengan alat digital refractometer (Atago Pcket PAL-1, Japan). Daging buah dihancurkan terlebih dahulu, cairan yang diperoleh diteteskan pada prisma refractometer dan secara otomatis nilai PTT akan terlihat pada pintu pembaca dalam satuan ${ }^{\circ}$ Brix. Sebelum digunakan, alat terlebih dahulu di kalibrasi dengan cara meneteskan aquades pada permukaan prisma refractometer dan menyesuaikan bacaan pada angka nol (0), kemudian dibersihkan dengan tissue lalu sampel dteteskan. (3) pH Daging Buah, pengukuran pH dilakukan menggunakan digital pHmeter (Shindengen Isfet KS 701, Japan). Alat di kalibrasi dengan cara meneteskan larutan buffer $\mathrm{pH}$ 6,9 pada permukaan sensor alat. Daging buah mangga di peras kemudian disaring dengan kertas saring selanjutnya hasil saringan diteteskan pada sensor $\mathrm{pHmeter}$. Setelah itu, alat akan bekerja secara otomatis sehingga muncul angka yang menunjukkan $\mathrm{pH}$ dari jus buah mangga.(4) Warna Buah, pengukuran warna pada daging buah dilakukan menggunakan alat colorimeter (AccuProbe HH 06, New York, USA). Alat colorimeter dihubungkan ke perangkat 
komputer, lalu alat dan komputer dinyalakan. Software "AccuWin 32" dibuka dan di setting sesuai perlakuan. Sampel diambil dan dilakukan pengukuran pada tiga titik (ujung, tengah dan pangkal buah) lalu tombol ditekan untuk mulai pengukuran. Standar warna yang digunakan berdasarkan skala Hunter L, a, dan b, dimana L menggambarkan keputihan warna (range $=0$ - 100; angka bertambah besar berarti lebih putih), huruf a menggambarkan warna merah/hijau (range $=(-128)$ - 127; + warna lebih merah; - warna lebih hijau), dan huruf $\mathrm{b}$ menggambarkan warna kuning/biru (range $=$ (-128) - 127; + warna lebih kuning; - warna lebih biru).

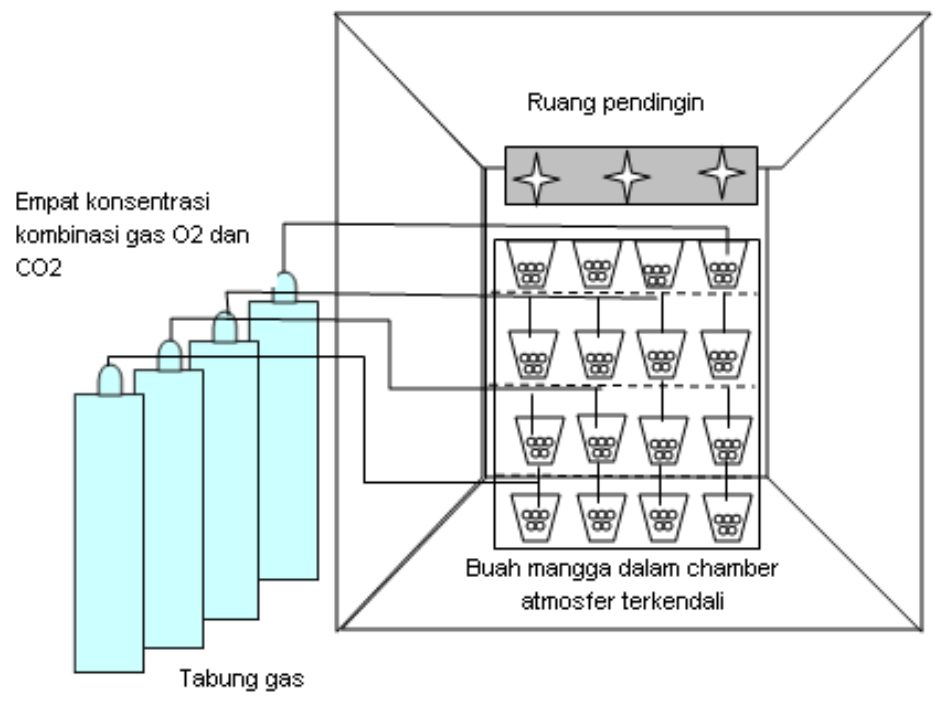

Gambar 1. Skematik instalasi controlled atmosphere storage (CAS) untuk buah mangga Arumanis

\section{Analisis Statistika}

Data dianalisis dengan analisis keragaman (Walpole dan Myers, 1978) dan bila terjadi pengaruh nyata akibat perlakuan terhadap parameter yang diukur, maka pengujian dilanjutkan dengan uji beda rata-rata antar aras perlakuan atau kombinasinya dengan menggunakan Duncan Multiple Range Test (DMRT 5\%).

\section{HASIL DAN PEMBAHASAN}

\section{Tekstur atau Kekerasan Daging Buah}

Laju penurunan kekerasan daging buah secara cepat terjadi pada suhu kamar (Gambar 2). Pada suhu penyimpanan ini, buah kontrol mengalami penurunan kekerasan secara dramatik cepat dibandingkan dengan buah yang diberi atmosfir terkendali. Pada penyimpanan suhu dingin, tekstur daging buah kontrol secara berarti lebih rendah selama penyimpanan dibandingkan dengan buah yang diberi perlakuan campuran gas $\mathrm{O}_{2}$ dan $\mathrm{CO}_{2}$. Ragam kombinasi campuran gas cenderung tidak memberikan pengaruh berarti terhadap kekerasan buah selama penyimpanan dingin. Secara jelas terlihat pada Gambar 2 bahwa hambatan penurunan kekerasan lebih berarti pada suhu dingin dan memperpanjang masa simpan. Penyimpanan dengan suhu dingin tetap menjadi pilihan utama untuk mempertahankan tekstur, sedangkan perlakuan atmosfir terkendali hanyalah bersifat additional dan bermanfaat dari aspek lainnya, seperti untuk menghindari transpirasi tinggi, menghambat pertumbuhan mikroorganisme perusak dan menghindari kerusakan mekanis (Kitinoja, 2001; Kader, 2002). 


\section{J. Hort. Indonesia 2(1):27-33. April 2011.}
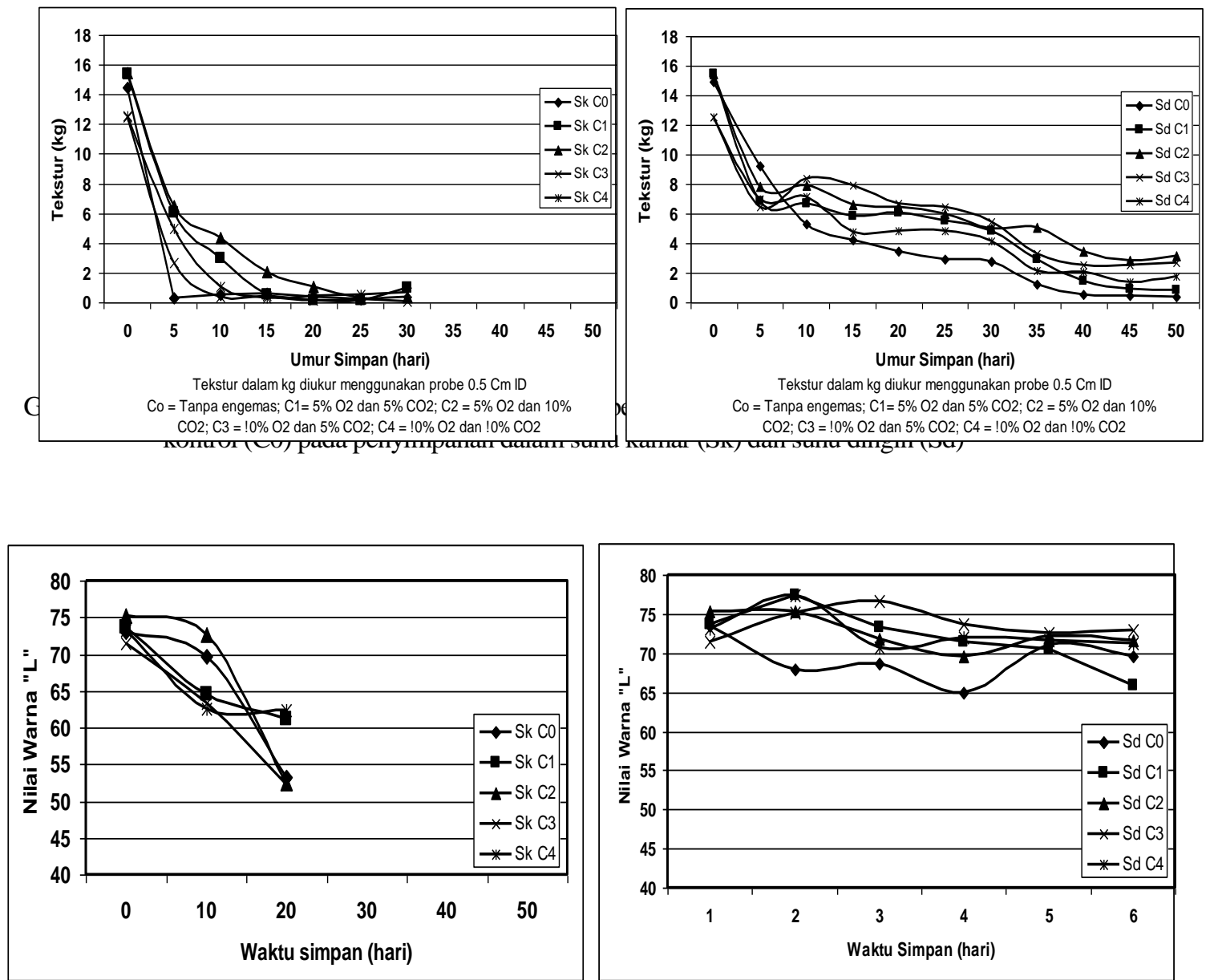

Gambar 3. Perubahan nilai warna $L^{*}$ daging buah yang diberikan perlakuan atmosfir terkendali (C1-C4) dan kontrol (C0) pada penyimpanan suhu kamar (Sk) dan suhu dingin (Sd) selama periode 0-50 hari

\section{Warna Daging Buah}

Laju penurunan nilai $\mathrm{L}^{*}$ daging buah pada suhu kamar sangat tinggi selama penyimpanan (Gambar 3). Perlakuan atmosfir terkendali pada penyimpanan suhu ini tidak menunjukkan pola yang jelas. Pada suhu dingin, penurunan laju nilai $\mathrm{L}^{*}$ relatif kecil, tetapi atmosfir terkendali memberikan penurunan nilai $\mathrm{L}^{*}$ daging buah lebih kecil dibandingkan dengan kontrol selama penyimpanan.
Pada suhu dingin, nilai warna $\mathrm{a}^{*}$ daging buah secara umum tidak ada perubahan selama penyimpanan, kecuali pada kontrol (Gambar 4). Mulai hari ke 10 nilai a* pada kontrol meningkat sampai hari ke 30, kemudian menurun sampai hari ke 50. Peningkatan nilai a* mencirikan adanya perubahan buah menuju kemerahan yang identik dengan terjadinya proses pemasakan buah. Penurunan yang terjadi karena berkembangnya areal kecil berwarna coklat yang menunjukkan adanya kerusakan dingin (chilling injury). Hasil yang sama didapatkan pada perubahan nilai b* (Gambar 5). 

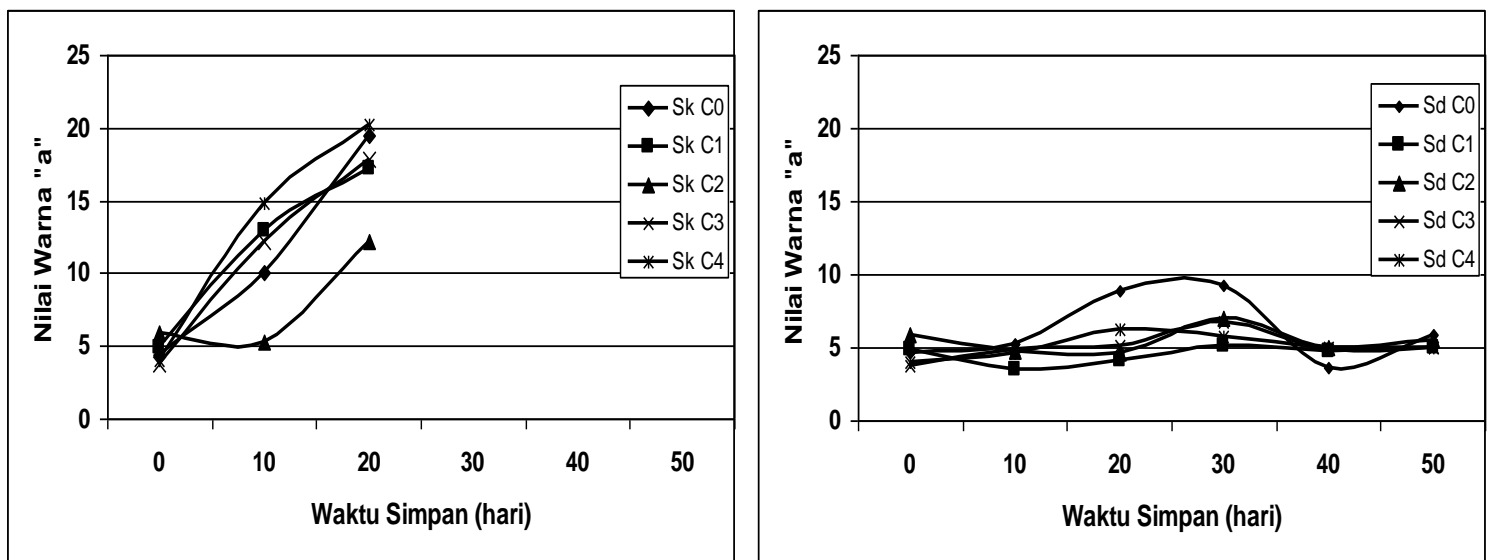

Gambar 4. Perubahan nilai warna $a^{*}$ daging buah yang diberikan perlakuan atmosfir terkendali (C1-C4) dan kontrol (C0) pada penyimpanan suhu kamar (Sk) dan suhu dingin (Sd) selama periode 0-50 hari.
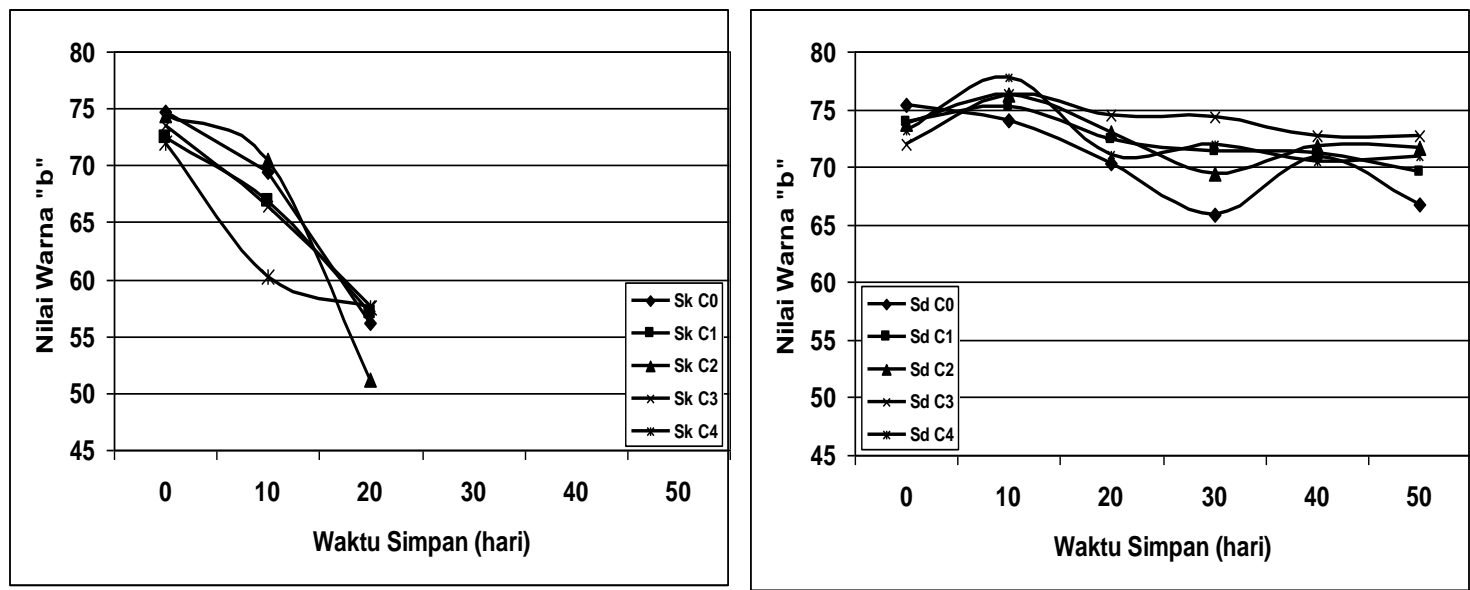

Gambar 5. Perubahan nilai warna $b^{*}$ daging buah yang diberikan perlakuan atmosfir terkendali (C1-C4) dan kontrol (C0) pada penyimpanan suhu kamar (Sk) dan suhu dingin (Sd) selama periode 0-50 hari.

Penurunan nilai $b^{*}$ berlangsung cepat pada suhu kamar dibandingkan suhu dingin. Hal ini berarti terjadi perubahan unsur nilai warna kuning menjadi lebih pekat yang mencirikan perubahan karena proses pemasakan buah. Buah kontrol cenderung mempunyai nilai warna $b^{*}$ lebih rendah dibandingkan daging buah yang diberi perlakuan atmosfir terkendali (C1-C4) walaupun perbedaan tersebut secara statistik tidak berarti selama periode penyimpanan 50 hari.

\section{Padatan Terlarut Total (PTT) Daging Buah}

Pada penyimpanan suhu dingin, PTT daging buah yang diberi perlakuan atmosfir terkendali yang berbeda tidak menunjukkan perbedaan secara berarti sampai memasuki periode penyimpanan ke 20 (Gambar 6). Perbedaan secara berarti muncul setelah periode penyimpanan tersebut, tetapi perubahan tersebut tidak berpola jelas untuk dapat membedakan satu dengan yang lainnya selama periode penyimpanan.

Perubahan PTT daging buah secara berarti disebabkan oleh suhu penyimpanan. Pada suhu kamar, perlakuan atmosfir terkendali memberikan pengaruh secara nyata terhadap laju perubahan PTT, tetapi perbedaan perubahan yang terjadi menjadi tidak bermanfaat akibat masa simpan yang singkat sampai hari ke 20 karena pada hari ke 25 buah untuk keseluruhan perlakuan telah mengalami pembusukan. Lain halnya dengan penyimpanan pada suhu dingin, masa simpan dibatasi oleh adanya gejala kerusakan dingin pada hari ke 50 . Dibandingkan dengan penyimpanan suhu kamar, perpanjangan masa simpan sampai hari 40-45 cukup berarti. 

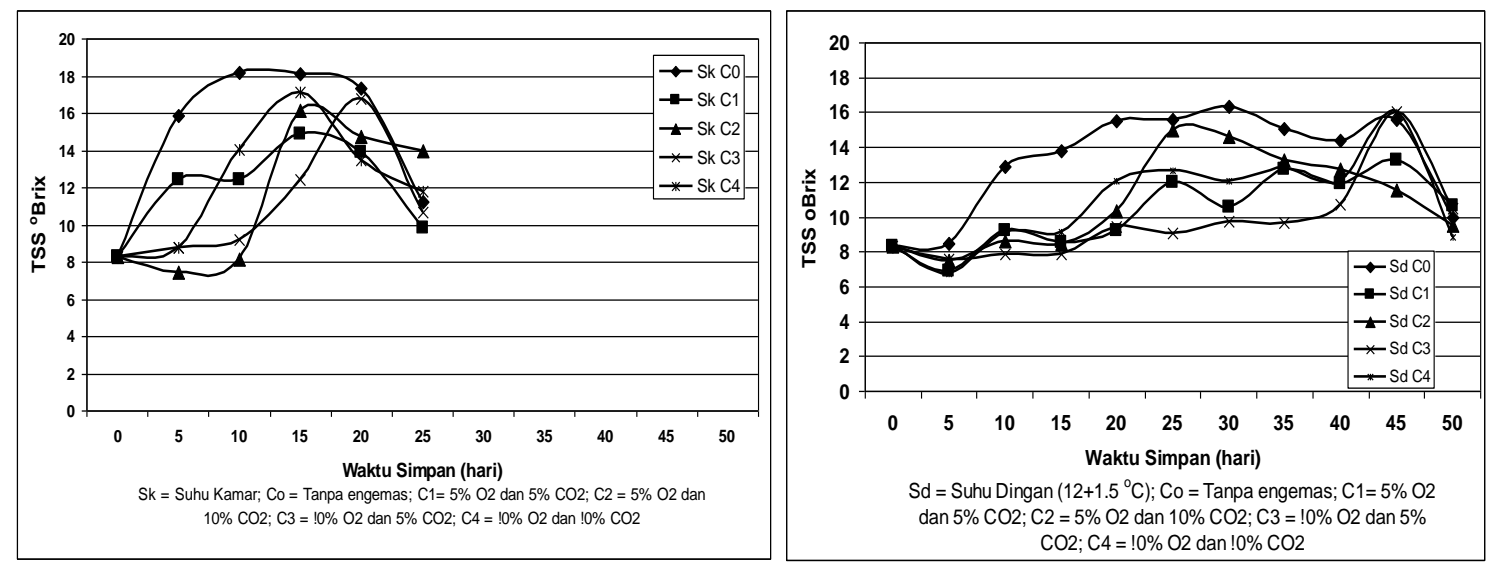

Gambar 6. Perubahan PTT daging buah ( ${ }^{\circ}$ Brix) yang diberi perlakuan atmosfir terkendali (C1-C4) dan kontrol (C0) pada penyimpanan suhu kamar (Sk) dan suhu dingin (Sd) selama periode penyimpanan 0-50 hari
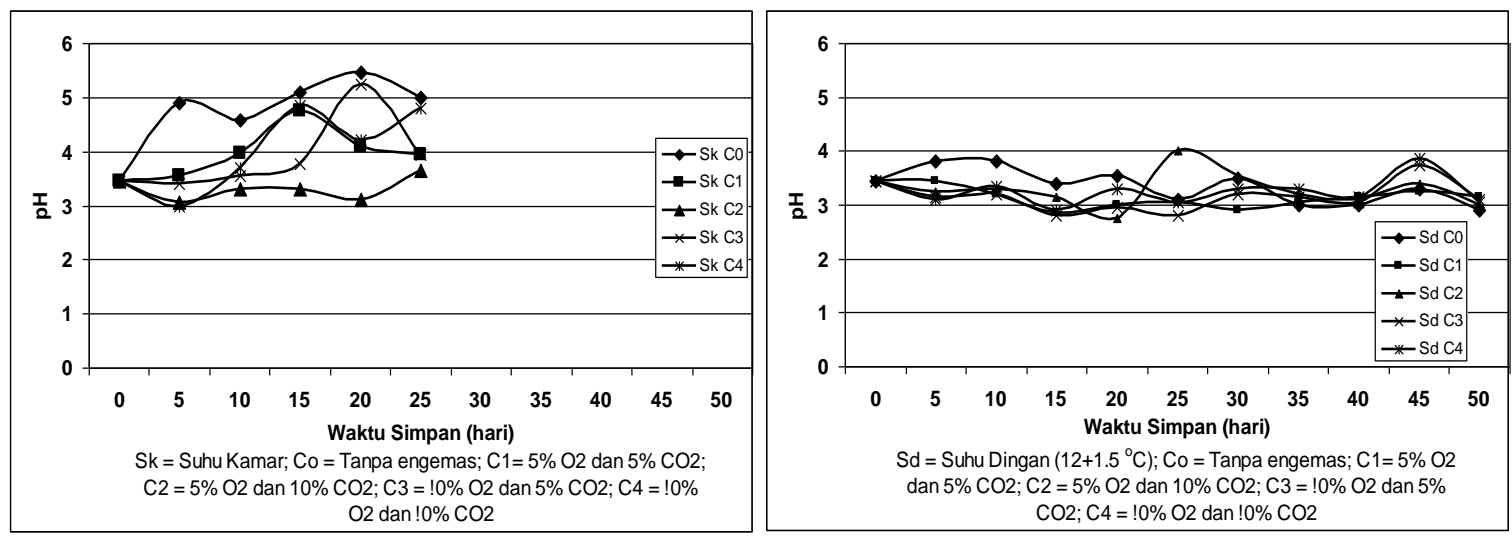

Gambar 7. Perubahan $\mathrm{pH}$ daging buah yang diberi perlakuan atmosfir terkendali (C1-C4) dan kontrol (C0) pada penyimpanan suhu kamar (Sk) dan suhu dingin (Sd) selama periode penyimpanan 0-50 hari.

\section{pH Daging Buah}

Penyimpanan pada suhu kamar, $\mathrm{pH}$ buah kontrol lebih tinggi dibandingkan dengan buah dengan perlakuan atmosfir termodifikasi sampai penyimpanan hari ke 25 pada saat buah telah mengalami pembusukan (Gambar 7). Tampak perlakuan $\mathrm{C} 2$ memberikan nilai $\mathrm{pH}$ terendah selama periode penyimpanan. Namun dilihat pada pengamatan PTT, pelonjakan PTT daging buah pada hari ke 15 pada perlakuan ini tidak menyebabkan pelonjakan terhadap $\mathrm{pH}$, walaupun sampai hari ke 10 nilai PTT relatif stabil

\section{KESIMPULAN}

- Penyimpanan pada suhu dingin $\left(12 \pm 1.5^{\circ} \mathrm{C}\right)$, perlakuan atmosfir terkendali tidak memberikan perbedaan nyata terhadap mutu dan masa simpan buah mangga Arumanis.

- Perlakuan atmosfir terkendali lebih baik untuk menurunkan laju proses kemunduran mutu buah mangga Arumanis dibandingkan buah ta1 pengendalian atmosfir pada penyimpanan suhu dingin.

- Penyimpanan pada suhu kamar $\left(28 \pm 2^{\circ} \mathrm{C}\right)$, perlakuan atmosfir terkendali memberikan perbedaan nyata terhadap mutu dan masa simpan buah mangga Arumanis, terlebih lagi dibandingkan dengan buah kontrol.

- Proses pembusukan buah berjalan cepat pada suhu kamar baik yang diberikan perlakuan atmosfir terkendali serta kontrol. 
- Penggunaan suhu dingin merupakan cara terbaik untuk mengendalikan laju metabolisme dan memperpanjang masa simpan buah mangga Arumanis.

- Atmosfir terkendali pada suhu ini tetap bermanfaat untuk mengendalikan laju transpirasi air buah yang rendah, sehingga masa simpan buah mangga Arumanis dapat sampai 40-45 hari.

\section{SARAN}

- Untuk memperpanjang masa simpan dan pemasaran jarak jauh buah mangga Arumanis, penyimpanan suhu dingin dan menyediakan rantai pendingin selama distribusi dan pemasarannya adalah cara terbaik. Untuk mencegah proses dehidrasi yang tinggi buah mangga Arumanis pada kondisi penyimpanan dingin dan selama pendistribusian serta pemasarannya yang menggunakan rantai pendingin, perlu dikaji pelibatan pengemasan individu dengan menggunakan plastik film.

- Penelitian lebih lanjut diperlukan untuk mengkaji atau menguji pemasakan secara normal pada buah mangga Arumanis setelah disimpan pada atmosfir terkendali dan suhu dingin, bila dikembalikan ke dalam suhu kamar setelah mengalami penyimpanan selama 40-45 hari pada suhu dingin $\left(28 \pm 2^{\circ} \mathrm{C}\right)$.

\section{DAFTAR PUSTAKA}

Aked, J. 2002. Maintaining the Postharvest Quality of Fruits and Vegetables. In Fruit and Vegetable Processing. Jorgan, W. (ed), Woodhead Pub. Ltd and CRC Press, LLC, Boca Raton FL, USA.

Badan Pusat Statistik. 2007. Statistik Indonesia. http: Ilwww.bps.go.id.

Bender, R.J., Brecht, JK., and Campbel, C.A. 1994. Response of Kent and Tomy Atkins mangoes to reduced $\mathrm{O}_{2}$ and elevated $\mathrm{CO}_{2}$. 107th Annual Meeting of the Florida State Horticultural Society, Orlando, Florida, USA, 30 Oct to 1 Dec 1994.
Ben-Yehoshua, S. 1991. New development in applying individual seal-packaging for improved handling of fruits and vegetables. In Proc. Int. Citrus Symp., Guangzhou, China (1990). Bangyan H. and Qian Y. (eds.): 755771.

Kader, A.A., 2002. Postharvest Tecnology of Horticultural Crops. University of California Agriculture and Natoral Resourch. USA.

Kays, S. J. 1991. Postharvest Physiology of Perishable Plant Products. An AVI Book, NY.

Kitinoja, L. 2001. Postharvest Handling of Fruits and Vegetables: Intended for Cold Storage. IARW India.

Lane, F.K, Surrey, K. 1974. Description of Pathogenic Fungi and Bacteria. Issued by The Commenwealth Mycological Inst, London.

Sommer, N.F. 1989. Manipulati the postharvest environment to enhance or maintain resistance. Phytopathol. 79(12):1377-339.

Thom, L., Gosbee, M., Johnson, P. 2002. Mango Sea Freight Trial Using Controlled and Modified Atmosphere Technology for Extending the Shelf Life of Mango Exports from the Northern Territory and Western Australia. A report prepared by Nothern Teritory Gov and Gov. of Western Australia.

Walpole, R.E., Myers, RH. 1978. Probability and Statistics for Engineers and Scientist. Mcmillan Pub. Co., Inc. Translated by Sembiring, R.K. and Suroso, ITB, Bandung.

Wills, R.B.H., T.H. Lee, D. Graham, W.B. Mc. Galsson, E.G. Hall. 1998. Postharvest, an Introduction to the Physiology and Handling of Fruits and Vegetables. The AVI Pub. Co. Inc. Westport, Connecticut.

Wilson, C. L. 1989. Managing the microflora of harvested fruits and vegetables to enhance resistance. Phytopathol. 79(12):1387-1390. 